\title{
DESAIN LEMBAR KERJA PESERTA DIDIK BERBASIS PREDICT OBSERVE EXPLAIN PADA PEMBELAJARAN FISIKA KELAS X SEMESTER I
}

\author{
Lelfita ${ }^{1}$, Nelfi Erlinda ${ }^{1}$ \\ ${ }^{1}$ Yayasan Dharma Bakti, Lubuk Alung \\ *Corresponding Address: lelfita@gmail.com
}

Naskah diterima: 9 Desember 2021| Disetujui: 19 Desember 2021 | Diterbitkan: 20 Desember 2021

\begin{abstract}
This research is motivated by the lack of attractive learning materials used by teachers, so that students have difficulties in understanding the lessons. One solution is to design learning materials in the form of Student Worksheets (LKPD) using a learning model that can improve the abilities and interests of students. The model used in the design of this LKPD is a model (Predict Observe Explain POE. The research carried out includes the type of Research and Development $(R \& D)$. The data collection instrument is an LKPD questionnaire based on the Predict Observe Explain model, a questionnaire to determine the practicality of the LKPD. LKPD based on the Predict Observe model Explain was tested at SMAN 2 Lubuk Alung Class X Semester 1. Based on the results of the LKPD validation analysis by the validator, a valid LKPD was obtained with an average score of $79.13 \%$ of the validity of the lecturer's questionnaire, and $80 \%$ of the validity of the teacher's questionnaire. POE-based LKPD which is very practical with an average score of $78.30 \%$ of the practicality of teachers, and $85.83 \%$ of practicality of students.
\end{abstract}

Keywords: $L K P D, P O E$

Abstrak: Penelitian ini dilakukan karena tidak menariknya bahan ajar yang digunakan guru dalam pembelajaran. Salah satu solusi yang dapat dilakukan adalah dengan mendesain bahan ajar berupa Lembar Kerja Peserta Dididik (LKPD) dengan model pembelajaran yang dapat meningkatkan kemampuan dan minat peserta didik. Adapun model yang digunakan pada desain LKPD ini adalah model (Predict Observe Explain) POE. Jenis penelitian ini adalah Research and Development (R\&D). Instrumen pengumpulan data adalah angket LKPD berbasis model Predict Observe Explain, dan angket praktikalitas untuk menentukan kepraktisan LKPD. LKPD berbasis model Predict Observe Explain dengan melakukan uji coba di SMAN 2 Lubuk Alung Kelas X Semester 1. Berdasarkan hasil analisis validasi LKPD oleh validator didapatkan LKPD yang valid dengan skor rata-rata 79,13\% dari validitas angket dosen dan $80 \%$ dari vaiditas angket guru. Hasil angket praktikalitas LKPD berbasis POE sangat praktis dengan skor rata-rata $78,30 \%$ dari kepraktisan guru dan $85,83 \%$ dari kepraktisan siswa, sehingga dapat disimpulkan bahwa LKPD berbasis model pembelajaran Predict Observe Explain didesain valid dan sangat praktis.

Kata kunci: LKPD, POE 


\section{PENDAHULUAN}

Perkembangan Ilmu Pengetahuan dan Teknologi (IPTEK) merupakan salah satu fakta yang memperlihatkan kondisi berkembang dan majunya suatu peradaban. Pengguna teknologi yang memiliki pengetahuan yang baik akan menggunakannya dengan baik pula, dan begitu juga sebaliknya. Dunia pendidikan ikut andil dalam memberikan pengaruh perkembangan zaman. Pendidikan yang sedang dijalani sangatlah berguna untuk kelangsungan hidup yang akan datang. Pendidikan mengajarkan tentang gejala-gejala yang terlihat dilingkungan sekitar, serta menyelesaikan masalah yang akan terjadi

Sains merupakan salah satu bidang ilmu yang ada dalam dunia pendidikan. Di mana salah satu cabang sains itu adalah ilmu fisika yang mempelajari tentang proses gejala alam seperti gelombang tsunami, gunung merapi, gempa bumi, aktivitas makluk hidup, dan perubahan cuaca. Proses gejala alam ini dipelajari dalam proses pendidikan. Fisika menjelaskan dan memperhitungkan tentang gejala fisik yang terjadi dialam semesta. Benda yang bergerak, bunyi yang berubah-ubah, warna-warni cahaya, dan lain sebagainya. Fisika juga terpakai penerapannya dalam bidang kedokteran dan industri seperti penggunaan sinar X, USG, dan lain-lain.

Pada Sekolah Menengah Pertama (SMP) ilmu fisika terangkum pada mata pelajaran Ilmu Pengetahuan Alam atau sering disebut IPA terpadu dan sudah dikenalkan tentang dasar-dasar fisika. Pada Sekolah Menengah Atas (SMA) pembelajaran ilmu fisika lebih mendalam dan lebih terfokus terhadap teori-teori fisika yang sudah ditemukan oleh ahli-ahli fisika terdahulu. Pembelajaran ilmu fisika pada jenjang pendidikan SMA merupakan kelanjutan dari pengenalan ilmu fisika yang sudah dipelajari pada waktu jenjang pendidikan SMP.

Fisika merupakan salah satu mata pelajaran yang ada pada jenjang sekolah menengah pertama maupun atas. Dalam belajar fisika sebaikanya fakta konsep dan prinsip-prinsip fakta tidak diterima secara prosedural tanpa pemahaman dan penalaran. Pengetahuan tidak dapat dipindahkan begitu saja dari otak seseorang (guru) ke orang lain (siswa). Siswa sendirilah yang harus mengartikan apa yang telah diajarkan dengan menyesuaikan terhadap pengalaman-pengalaman mereka. Pengetahuan atau pengertian dibentuk oleh siswa secara aktif, bukan hanya diterima secara pasif dari guru.

Mengingat pentingnya fisika dalam ilmu pengetahuan, maka upaya memperbaiki dan meningkatkan mutu pendidikan tidak akan pernah berhenti. Usaha yang dilakukan pemerintah untuk meningkatkan mutu tersebut seperti penyempurnaan kurikulum, menyediakan sarana dan prasarana, melakukan pelatihan dan seminar bagi guru-guru, pendekatan dan model pembelajaran yang inovatif, sampai dengan penyediaan media pembelajaran. 
Pembelajaran fisika yang baik dapat terlaksana ketika sebelum pembelajaran fisika dalam kelas, siswa sudah mempelajari sendiri tentang apa yang akan dipelajari dan itu terjadi setelah mendapatkan arahan serta petunjuk dari guru. Siswa yang sudah mempelajari sendiri materi pembelajaran fisika memiliki pertanyaan tersendiri. Dalam kondisi ini, siswa sudah memiliki pola prediksinya dalam memahami pelajaran fisika tersebut. Kondisi ini sangat membantu guru dalam mengembangkan kemampuan kognitif siswa dalam pembelajaran fisika, serta dalam kegiatan penyampaian masalah tersebut siswa akan terlatih sikapnya terhadap pemecahan masalah yang didapatinya.

Berdasarkan observasi di sekolah, guru hanya memanfaatkan bahan ajar seperti buku cetak yang masih belum memadai untuk mengaktifkan siswa. Dengan hanya menggunakan bahan ajar cetak, siswa lebih banyak menerima dari guru tanpa ada usaha dari siswa itu sendiri. Selain itu, siswa lebih sulit memahami materi karena bahasa yang digunakan kurang dimengerti oleh siswa. Dengan banyaknya materi pada buku cetak membuat siswa bosan untuk membacanya, karena pada umumnya peserta didik sangat malas untuk membaca, sehingga peserta didik kurang termotivasi pada pembelajaran fisika. Berdasarkan masalah yang terjadi, guru harus mampu membuat bahan ajar sendiri yang bisa mengaktifkan peserta didik. Salah satu bahan ajar yang bisa dibuat sendiri oleh guru adalah Lembar Kerja Peserta Didik (LKPD).

LKPD merupakan suatu bahan ajar cetak yang berupa lembar-lembar kertas yang berisi materi ringkasan dan petunjuk pelaksanaan pembelajaran yang harus dikerjakan peserta didik, baik bersifat teoritis maupun praktis, yang mengacu pada kompetensi dasar yang harus dicapai peserta didik (Prastowo, 2014). Dengan menggunakan LKPD memungkinkan siswa untuk belajar sendiri tanpa harus tergantung pada guru. Selain itu siswa dapat belajar tanpa harus terikat dengan tempat maupun waktu. Siswa diharapkan dapat mengikuti program pembelajaran secara mandiri, dapat mengetahui hasil belajar sendiri, serta menekankan penguasaan bahan pelajaran secara optimal.

Dalam proses pembelajaran, terdapat beberapa teknik yang dapat digunakan untk membantu proses pembelajaran, salah satunya adalah teknik Predict Observe Explain (POE). Teknik pembelajaran POE adalah teknik pembelajaran yang dikembangkan oleh Warsono. Teknik pembelajaran ini menekankan pada sikap-sikap ilmiah seperti meramalkan dan memprediksi, kemudian mengujinya dengan observasi dan memberikan penjelasan tentang kesesuaian antara prediksi dengan hasil observasi. Apabila hasil prediksi tersebut sesuai dengan hasil observasi, maka peserta didik akan semakin yakin dengan konsepnya. Jika dugaan peserta didik tidak tepat, maka peserta didik dapat mencari penjelasan tentang ketidakpastian prediksinya. Peserta didik akan mengalami perubahan konsep dari konsep yang tidak benar menjadi benar. Oleh karena itu, peserta didik dapat belajar dari kesalahan dan biasanya belajar dari kesalahan dan tidak akan mudah 
dilupakan. Penggunaan teknik pembelajaran POE dapat menjadi strategi pengajaran yang efektif untuk memfasilitasi pemahaman siswa terhadap suatu konsep.

Teknik POE dapat meningkatkan pemahaman konsep sains peserta didik. Teknik ini dapat digunakan untuk menggali pengetahuan awal peserta didik, memberikan informasi kepada guru mengenai kemampuan berpikir peserta didik, mengkondisikan peserta didik untuk melakukan diskusi, memotivasi peserta didik untuk mengeksplorasi konsep yang dimiliki, dan membangkitkan peserta didik untuk melakukan investigasi. Teknik ini merupakan salah satu model berorientasi konstruktivisme yang menekankan pada cara peserta didik membangun atau menemukan pengetahuan sendiri. Teknik ini melatihkan peserta didik untuk memberikan prediksi atau jawaban sementara dari permasalahan yang diberikan oleh guru (Ratna, 2013).

LKPD berbasis POE (Predict Observe Explain), adalah salah satu alternatif solusi dari pemasalahan di atas. LKPD berbasis POE adalah salah satu bentuk bahan ajar yang disusun berdasarkan langkah-langkah pembelajaran teknik POE. Teknik POE adalah teknik pembelajaran yang menggunakan tiga langkah utama metode ilmiah yaitu prediksi, observasi, dan eksplanasi. Teknik POE akan mengarahkan peserta didik memecahkan suatu persoalan melalui tiga langkah utama metode ilmiah. Pertama, peserta didik harus memprediksi suatu peristiwa dan harus memberikan alasan yang membenarkan prediksi mereka secara teori. Kedua, mereka melakukan observasi dan selanjutnya peserta didik harus memberikan penjelasan terkait prediksi dan observasi. Langkah-langkah teknik POE menjadikan peserta didik aktif untuk membuktikan sendiri prediksinya. Langkah pertama dalam teknik POE ini adalah membuat prediksi atau dugaaan.

Pada tahap pertama adalah tahap prediksi, guru memberikan fenomena kepada peserta didik, kemudian peserta didik memberikan prediksi apa yang akan terjadi. Guru meminta peserta didik untuk memprediksi kejadian yang akan terjadi atau jawaban dari permasalahan yang disajikan. Prediksi peserta didik harus berdasarkan teori dan alasan. Peserta didik memberikan penjelasan meyakinkan bahwa hasil prediksi mereka benar. Langkah kedua yaitu melakukan observasi atau pengamatan. Pada tahap observasi peserta didik mengamati fenomena dan guru membimbing peserta didik melakukan pengamatan agar sesuai dengan konsep. Peserta didik dapat membuktikan dugaan yang diajukan dengan melakukan observasi atau pengamatan melalui kegiatan eksperimen dan demonstrasi. Pada langkah observasi atau pengamatan peserta didik dapat mengamati demonstrasi dari guru, percobaan secara berkelompok, penyelidikan secara berkelompok atau mengumpulkan informasi dari berbagai buku atau sumber belajar lainnya. Langkah ketiga yaitu membuat penjelasan ekplanasi adalah memberikan penjelasan tentang kesesuaian antara dugaan dan yang sungguh terjadi. Peserta didik diminta untuk membuat penjelasan terkait dengan dugaan yang mereka buat dan hasil dari observasi. Jika prediksi sesuai dengan hasil observasi, maka peserta didik akan merasa lebih 
yakin terhadap suatu konsep. Jika prediksi tidak sesuai dengan hasil observasi, maka peserta didik harus mencari alasan mengapa prediksi mereka salah. Guru dapat membantu peserta didik dalam menemukan kesalahan dalam dugaannya, mengubah prediksi, dan membenarkan prediksi yang tadinya keliru serta kesalahan-kesalahan dalam melakukan pratikum (Ira, 2015).

Berdasarkan uraian permasalahan yang telah dikemukakan, peneliti tertarik untuk mendesain lembar kerja peserta didik berbasis teknik pembelajaran POE, sehingga peneliti berkeinginan melakukan penelitian dengan judul "Desain Lembar Kerja Peserta Didik Fisika Berbasis Predict Observe Explain Pada Pembelajaran Fisika Kelas X Semester 1 SMAN 2 Lubuk Alung.

\section{METODE}

Sesuai dengan tujuan penelitian yaitu mendesain lembar kerja siswa berbasis teknik Predict Observe Explain (POE), maka jenis penelitian yang digunakan adalah Research and Development $(R \& D)$. Populasi dalam penelitian ini adalah seluruh peserta didik kelas X IPA SMAN 2 Lubuk Alung, kemudian sampelnya diambil dengan teknik Simple Random Sampling. Penelitian ini dilakukan dengan tiga tahap, yaitu tahap pembuatan lembar kerja peserta didik, tahap pembuatan angket/kuiesioner, dan tahap pengembangan (Develop). Teknik analisis data jenis skala Likert digunakan dalam menganalisis data pada penelitian ini.

\section{HASIL DAN PEMBAHASAN}

Bahan ajar yang dibuat dalam bentuk Lembar Kerja Peserta Didik (LKPD) kelas X berbasis teknik Predict Observe Explaind (POE) telah selesai dibuat. LKPD yang dikembangkan terdapat beberapa komponen diantarannya cover, petunjuk belajar, kompetensi dasar, indikator, tujuan, pendahuluan, materi, sintak teknik pembelajaran POE, uji kompetensi, dan kunci jawaban

\section{Hasil Validasi LKPD}

LKPD yang telah didesain dalam penelitian ini adalah LKPD berbasis POE pada pembelajaran fisika kelas X. LKPD yang didesain adalah untuk satu semester. LKPD yang telah didesain divalidasi oleh validator untuk melihat valid atau tidaknya LKPD untuk diujicobakan. Data yang dideskripsikan adalah data yang diperoleh dari jawaban angket dosen dan guru yang berjumlah 2 orang dosen Fisika, 1 orang dosen Bahasa Indonesia dan 2 orang guru Fisika.

Data yang diperoleh kemudian dianalisis, sehingga diperoleh skor rata-rata valid suatu lembar kerja siswa berbasis predict observe explain mata pelajaran Fsika seperti terlihat pada tabel hasil kevalidan oleh dosen dan guru berikut. 
Tabel 1. Hasil Validasi LKPD Fisika oleh Dosen

\begin{tabular}{|c|c|c|c|c|c|c|}
\hline \multirow{3}{*}{ No } & \multirow{3}{*}{$\begin{array}{c}\text { Tim } \\
\text { Validator }\end{array}$} & \multirow{2}{*}{\multicolumn{3}{|c|}{$\begin{array}{c}\text { Penilaian (\%) } \\
\text { Validator }\end{array}$}} & \multirow{3}{*}{$\begin{array}{c}\text { Skor } \\
\text { Nilai } \\
\text { Validasi } \\
(\%)\end{array}$} & \multirow{3}{*}{ Kategori } \\
\hline & & & & & & \\
\hline & & EB & FU & $\overline{\mathrm{DM}}$ & & \\
\hline 1 & Dosen & 98 & 90 & 85 & 79,13 & Valid \\
\hline
\end{tabular}

Tabel 2. Hasil Validasi LKPD oleh Guru

\begin{tabular}{|c|c|c|c|c|c|}
\hline \multirow{3}{*}{ No } & \multirow{3}{*}{$\begin{array}{c}\text { Tim } \\
\text { Validator }\end{array}$} & Peni & n(\%) & \multirow{3}{*}{$\begin{array}{c}\text { Skor Nilai } \\
\text { Validasi } \\
(\%)\end{array}$} & \multirow{3}{*}{ Kategori } \\
\hline & & \multicolumn{2}{|c|}{ Validator } & & \\
\hline & & TS & WD & & \\
\hline 1 & Guru & 30 & 34 & 80 & Valid \\
\hline
\end{tabular}

Dari tabel di atas terlihat analisis kevalidan dari data angket dosen dan guru secara keseluruhan dengan menggunakan skala Likert diperoleh nilai rata-rata kevalidan LKPD Fisika berbasis POE yaitu $79,13 \%$ dan $80 \%$.

\section{Hasil Praktikalitas LKPD}

Data yang dideskripsikan adalah data yang diperoleh dari jawaban angket guru fisika. Data yang diperoleh kemudian dianalisis sehingga diperoleh skor rata-rata kepraktisan seperti yang terlihat pada tabel 3 berikut.

Tabel 3. Hasil Praktikalitas LKPD Fisika oleh Guru

\begin{tabular}{|c|c|c|c|c|c|}
\hline \multirow{3}{*}{ No } & \multirow{3}{*}{$\begin{array}{c}\text { Tim } \\
\text { Validator }\end{array}$} & $\mathbf{P e}$ & aian (\%) & \multirow{3}{*}{$\begin{array}{c}\text { Rata- } \\
\text { Rata } \\
(\%)\end{array}$} & \multirow{3}{*}{ Kategori } \\
\hline & & \multicolumn{2}{|c|}{ Validator } & & \\
\hline & & TS & WD & & \\
\hline 1 & Guru & 51 & 43 & 78,33 & Praktis \\
\hline
\end{tabular}

Analisis kepraktisan dari data angket oleh 2 (dua) orang guru fisika SMAN 2 Lubuk Alung secara keseluruhan dengan menggunakan skala Likert diperoleh nilai rata-rata kepraktisan LKPD Fisika berbasis POE yaitu 78,33\%.

Praktikalitas LKPD oleh peserta didik dilakukan pada siswa kelas X MIPA SMAN 2 Lubuk Alung yang berjumlah 23 siswa. Data yang diperoleh kemudian dianalisis dan diperoleh skor ratarata kepraktisan. Kepraktisan LKPD berbasis POE dapat dilihat dari isi, bentuk, motivasi, dan kepraktisan. Analisis kepraktisan dari data angket peserta didik secara keseluruhan dengan menggunakan skala Likert diperoleh nilai rata-rata kepraktisan berbasis POE yaitu $85,67 \%$ dan berarti berada pada kategori ini sangat praktis. 
Lembar kerja peserta didik berbasis POE adalah salah satu bentuk bahan ajar yang disusun berdasarkan langkah-langkah pembelajaran teknik POE. Teknik POE adalah teknik pembelajaran yang menggunakan tiga langkah utama metode ilmiah yaitu prediksi, observasi, dan eksplanasi. Teknik POE akan mengarahkan peserta didik untuk memecahkan suatu persoalan melalui tiga langkah utama metode ilmiah. Peserta didik harus memprediksi suatu peristiwa dan harus memberikan alasan yang membenarkan prediksi mereka secara teori, kemudian mereka melakukan observasi dan memberikan penjelasan terkait prediksi dan observasi.

Hasil pengolahan data angket yang diisi oleh dosen, guru, serta siswa terkait LKPD berbasis POD untuk mata pelajaran Fisika kelas X dapat diuraikan sebagai berikut:

A. Dosen

Untuk mengetahui kevalidan LKPD berbasis POE yang dikembangkan beradasarkan validasi dosen dapat ditinjau dari beberapa aspek berikut:

1. Kelayakan Komponen Penyajian, yang dinyatakan baik

2. Komponen bahasa, yang dinyatakan baik

3. Komponen isi, yang dinyatakan baik

B. Guru

Untuk mengetaui kevalidan LKPD berbasis POE yang dikembangkan berdasarkan validasi oleh guru dapat ditinjau dari beberapa aspek berikut:

1. Isi, dinyatakan sangat baik

2. Bentuk, dinyatakan baik

3. Motivasi, dinyatakan baik

C. Siswa

Dari angket praktikalitas yang diberikan kepada siswa,maka untuk menghitung data kepraktisan dapat ditinjau dari beberapa aspek berikut:

1. Bentuk, dinyatakan sangat baik

2. Isi, dinyatakan sangat baik

3. Motivasi, dinyatakan sangat baik

4. Kepraktisan, dinyatakan sangat baik

5. Kegunaan, dinyatakan sangat baik

\section{KESIMPULAN}

Berdasarkan pembahasan yang telah diuraikan di atas diperoleh kesimpulan bahwa dari segi validitas angket oleh dosen pada aspek produk dan aspek instruksional diperoleh skor rata-rata 
79,13\% dengan katogori valid. Untuk validitas oleh guru berupa isi, bentuk/tampilan, dan motivasi memperoleh skor rata-rata 80\% dengan katogori valid dan kepraktisannya 78,3\% dengan kategori praktis. Sedangkan untuk kepraktisan dari angket yang diisi oleh siswa memperoleh skor rata-rata 85,83\% dengan kategori sangat praktis, sehingga dapat ditarik kesimpulan desain LKPD fisika berbasis POE satu semester valid dan praktis

Dari hasil penelitian ini, penulis memberikan beberapa saran, antara lain LKPD berbasis POE satu semester ini dapat digunakan oleh guru sebagai bahan ajar dalam kegiatan belajar mengajar, LKPD berbasis POE satu semester ini dapat dimanfaatkan oleh siswa sebagai latihan dirumah, serta untuk peneliti selanjutnya alangkah baiknya peneliti melakukan 1 semester.

\section{DAFTAR PUSTAKA.}

Majid,Abdul. (2013). Strategi Pembelajaran .Remaja Rosdakarya: Bandung

Prastowo, Andi. (2014). Pengembangan Bahan Ajar Tematik. Jakarta: Prenandamedia Group

Rizal, Ira Lestari dkk. 2015. Pengaruh Penggunaan LKS Berbasis POE Dalam belajaran IPA Terhadap Komptensi Siswa Kelas VII SMPN 5 Padang. Jurnal Pendidikan Fisika. Padang: Universitas Negeri Padang

Sugiyono. 2015. Metode Penelitian Pendidikan. Bandung Alfabeta

Sumiati. (2007). Metode Pembelajaran Pendekatan Individual. Bandung: Rancaekek Kncana

Warsono \& Hariyanto. (2012). Pembelajaran Aktif. Bandung: Remaja Rosdakarya

Widyaningrum, Ratna dkk. 2013. Pengembangan Modul Berorientasi POE (Predict, Observe, Explain) Berwawasan Lingungan pada Marteri Pencemaran Untuk Meningkatkan Hasil Belajar Siswa. Jurnal Studi 